Afric

ArXiv

Article title: Professional Variables and Staff Readiness to Utilise Internet-Based Channels for Research

Communication in an Era of Covid-19

Authors: Valentine Joseph Owan[1], Levi Udochukwu Akah[2], Mary Mark Ogbeche[3]

Affiliations: Department of Educational Management, University of Calabar, PMB 115, Etta Agbor Street, Calabar, Cross River State, Nigeria[1], Department of Human Kinetics and Health Education, University of Calabar, PMB 115, Etta Agbor

Street, Calabar, Cross River State, Nigeria[2]

Orcid ids: 0000-0001-5715-3428[1], 0000-0002-4096-896X[2]

Contact e-mail: owanvalentine@gmail.com

License information: This work has been published open access under Creative Commons Attribution License http://creativecommons.org/licenses/by/4.0/, which permits unrestricted use, distribution, and reproduction in any medium, provided the original work is properly cited. Conditions, terms of use and publishing policy can be found at https://www.scienceopen.com/.

Preprint statement: This article is a preprint and has not been peer-reviewed, under consideration and submitted to AfricArXiv Preprints for open peer review.

Links to data: https://doi.org/10.17632/69k939yr4n.2

DOI: $10.14293 / 111.000 / 000019 . v 1$

Preprint first posted online: 23 June 2021

Keywords: Africa, Covid-19, Internet tools, Professional variables, Research, Staff readiness 


\title{
Professional Variables and Staff Readiness to Utilise Internet-Based Channels for Research Communication in an Era of Covid-19
}

\author{
Valentine Joseph Owan ${ }^{1 *}$, Levi Udochukwu Akah ${ }^{2}$, Mary Mark Ogbeche ${ }^{1}$, Moses Eteng Obla ${ }^{3}$ \\ ${ }^{I}$ Department of Educational Management, University of Calabar, Calabar, Nigeria \\ ${ }^{2}$ Department of Human Kinetics and Health Education, University of Calabar, Nigeria \\ ${ }^{3}$ Department of Curriculum Studies, University of Calabar, Nigeria. \\ *Corresponding Author: owanvalentine@gmail.com
}

\begin{abstract}
This study assessed the professional variables of academic staff in African varsities and their readiness to Utilise Internet-Based Channels for Research Communication in an era of Covid19. Drawing from Maslow's hierarchy of needs theory, the study was guided by four null hypotheses. The quantitative research method based on the virtual cross-sectional survey design was adopted. A total of 8,591 academics in African universities were the targeted demographic of this study. However, data were collected from a virtual snowball sample of 1,977 respondents (males, $\mathrm{N}=1347$; females, $\mathrm{N}=630$ ) from 24 African countries. A validated electronic survey, with three major aspects, was employed for data collection. The e-survey was released on the Association of African Universities' Telegram forum, which includes 1,622 participants from diverse African nations and regions. Members of the forum, who are all academics, were invited to complete the survey and publish it on their universities' internetbased forums. Coded data were analysed using descriptive and inferential statistics such as the Kruskal Wallis Non-parametric test. The non-parametric test was used because the data failed to meet the normality assumptions required to perform a parametric test. Results indicated, amongst others, that there are considerable variances in staff preparedness to use internet-based channels for research communication based on their educational credentials, educational qualification, rank and areas of research interest. According to the survey, academics with a doctoral degree; grade II lecturers; staff with 3 to 6 years of service; and staff in the medical sciences demonstrated a higher propensity of readiness to use internet-based channels for research communication. Based on these findings key theoretical, practical and research implications are discussed.
\end{abstract}

Keywords: Africa, Covid-19, Internet tools, Professional variables, Research, Staff readiness.

\section{Introduction}

Coronavirus is a microscopic agent that causes an infectious disease in both animals and humans. In 1937, evidence shows that scientist identified the venom in birds and isolated one that was responsible for a type of inflammation of the bronchus and had the potential to ruin poultry stocks. In the 1960 s, evidence of human coronavirus was discovered in the noses of humans with the common cold. Nevertheless, in December 2019, a coronavirus outbreak was identified in Wuhan, a city in Hubei, province of China. Experts named the newly identified virus the Severe Acute Respiratory Syndrome Coronavirus 2(SARs-CoV-2) and the illness it causes, coronavirus disease 19 (Covid-19), according to World Health Organisation (hereafter WHO, 2020). Since then, the virus has mostly spread through person-to-person contact, with the first case reported by Wuhan Municipal Health Commission on December 31, 2019. 
Nevertheless, the Special Expert Group for Control of the Epidemic of Novel Coronavirus Pneumonia (SEGCENCP) of the Chinese Preventive Medicine Association (CPMA, 2020) suggested that the new strain of coronavirus is traceable to bats (Rhinolophus sinicus). On the contrary, some studies suggest that pangolins may be the origin of the virus (Liu et al., 2019; Yang et al., 2021; Zhang et al., 2020). In South-East Asia, a study found evidence of SARSCov-2 and other forms of coronaviruses in both and Pangolins (Wacharapluesadee et al., 2021). In Malaysia, two independent studies had no proof of the presence of Coronavirus in Pangolins (Lee et al., 2020; Xiao et al., 2020). Although there is little conclusive information about the origin of the virus and it remains unclear how the virus first spread to humans. Globally, the outbreak is sudden, making it difficult to give a detailed estimate of how often the disease becomes severe or the exact rate of mortality it has caused.

In any case, empirical evidence abounds that out of 1,099 people with confirmed cases in China, around $16 \%$ became severe, while another report estimates that about $3.6 \%$ of confirmed cases in China led to death (Chen, et al., 2020). These figures keep changing exponentially as the situation keeps evolving, while the mortality rate varies from country to country. At the time of writing, there are over 129,692,131 confirmed cases, 2,831,505 death cases and 104,558,722 recoveries globally; with several African countries imposing a range of preventive and containment measures against the exponential spread of the pandemic. According to the latest data by the John Hopkins University, and Africa Center for Disease Control on Covid-19 pandemic, the confirmed cases in Africa are 874,036, active cases 330,981 , recovered cases 524,557, while death cases are 18,498. The breakdown remains fluid as countries keep confirming cases daily. As of May 13, 2020, every African country had recorded an infection, and as many as 213 countries and territories have registered COVID-19 cases worldwide; while the entire globe bemoaned with uncertainty and persistent fear of losing their loved ones (Cohut, 2020). In Nigeria, the situation, according to the Nigeria Centre for Disease Control (NCDC, 2021) and at the time of writing, the total confirmed cases were 162,891, 2,057 deaths and 151,648 recoveries or discharge cases. Apart from the fear imposed on humans, the Covid-19 pandemic also brought about physical distancing; thus, welcoming the amplification of remote works. Research happened to be amongst the work that can be done remotely. This means that the Covid-19 pandemic has ushered in a new paradigm in the way research can be conducted and communicated. A couple of years back, research and dissemination were done in person (where the researcher would have to meet targeted participant face-to-face and dissemination was through the use of traditional channels). In some cases, researchers may have to visit locations in different cities to get a wider cross-section of the people. Thus, ideas were limited to scholars' locality, which never gave research a wider scope. Research dissemination and consumption during this era were through books, materials, newspapers, and magazines.

Admittedly, even before the emergence of the Covid-19 pandemic, the print format of research dissemination was disrupted by the internet-based channels and digital network technologies. This made it possible for more scholarly journals and books to take both electronic and print forms for increased visibility and wide coverage. Nevertheless, these traditional research communication vehicles have retained similar functions and formats during this period of transition. Undoubtedly, the use of internet-based channels is unavoidable for research dissemination, owing to the numerous benefits (timeliness, citation tracking, speedy information access, increased visibility and so on) associated with online dissemination of published researches or pre-prints. Sadly, most researchers are, so far, still near the start of adopting internet-based channels in communicating their research results. Generally, internetbased channels for research communication refers to the platforms that enable can be deployed 
by researchers to spread their published or unpublished works to a wider audience. Academics should be willing to adopt and deploy internet-based resources in order to benefit from the promise of the digital environment (Owan, Asuquo, Makuku et al., 2021). These channels invoke new ways of reaching and actively involving a greater number of audiences beyond the primary dissemination target and help to actively involve peers and others who would otherwise be restricted through the traditional method of research communication. According to Williams et al. (2017), the adoption and utilization of these new vents can as well lead to new cross-disciplinary collaborations and help to facilitate new researches, dissemination, and funding opportunities for researchers.

Ross-Hellauer et al. (2020) averred that these powerful trends toward responsible research and innovation; the increasing globalization of research, and the emergence as well as the inclusion of new or previously excluded communities and stakeholders, are also helping to reshape the aim of research dissemination towards reaching a new area of coverage and nature of audiences. However, emphasis on engagement and participation of non-research audience has also brought about new forms of research dissemination (Stilgoe, et al., 2014). Today, countries are faced with the challenge of forcing the new educational system to work at its best to meet up with the shock associated with the Covid-19 pandemic, which has provoked a very large disruption of the global economy to almost a total collapse due to the compulsory lockdown. Recent policies put in place in a short time by the government to ameliorate the shock of the COVID-19 pandemic have led, in many countries to a massive downward economic retrogression effect at the end of the lockdown. The consequences are glaring on the education systems of nations and Nigeria and other African countries are taking a lion share. Placing growing pressure on global education, the closure of institutions, forced countries to adapt to the online environment with immediate effect for their academic activities. There are several online platforms available for academics to leverage (Nash \& Churchill, 2020; Rangaswamy et al., 2020). However, challenges remain with developing countries like Nigeria. Issues of unequal access to internet facilities, epileptic power supply, limited and unstable internet connectivity by service providers, unavailability of e-research gadgets, unaffordable data, insufficient broadband services, along an increasing financial crisis, tend to prevent massive internet use in developing countries. Against these odds, many researchers are confronted with the challenge of conducting studies on areas and locations which are quite essential to them. Those working on field-oriented researches may struggle to collect data, especially in studies involving human subjects. Potential respondents and/or research assistants may decline any invitation to participate in any research activity for health and safety concerns.

In a global survey of the International Association of Universities (IAU) on the impact of COVID-19 on higher education around the world, Marinoni, et al. (2020) notes that $80 \%$ of HEIs reported that the Covid-19 pandemic has affected their institutional research. However, $83 \%$ of them noted that cancellation of international travel happened to be the most common impact, while $81 \%$ noted that cancellation and postponement of scientific conferences posed a very big challenge to them. Moreover, 50\% pointed out that their scientific research works are at risk of not been completed at the set time. In a study, Jeyshankar et al. (2016) investigated the access to and utilization of Internet services among postgraduate students of six rural colleges in India. The respondents have excellent skills in using internet communication tools for sharing and communicating research information with others. The research of Ashraf and Haneefa (2016) investigated the scholarly use of Internet facilities by doctoral students at the University of Calicut, Kerala. The analysis revealed that the majority of the students are aware and are using the Internet facility for scholarly purpose and mainly for locating scholarly content and current global information. In another study conducted in India, Singh and Gill 
(2015) revealed that the Internet is the most popular communication tool used by all categories of research respondents. In Aligarh Muslim University, Munshi (2015) studied the use of internet communication tools for academic purposes among engineering students and discovered that the majority of the students are dependent on Internet communication tools for their research activities and communication purposes. In 2015, Divya and Sudhier studied the use of internet tools and services by research scholars of the ten different faculties of applied sciences at the University of Kerala. The study revealed that the majority of the research scholars used internet services for e-journal access and research communication. However, the results showed that e-mail is the most commonly used Internet-based service among research scholars.

According to Sahoo and Sharma (2015), the interactive usage of the Internet facility can be addressed as part of the library system for research undertakings among scholars. Similarly, Kumar and Kumar (2013) studied the activities and reasons for Internet use by postgraduate students and research scholars of Maharishi Dayanand University, Rohtak. It was found that the majority of the respondents were aware and making active use of Internet-based services in their research activities. According to Park (2011), Wikipedia is by now a well-established and reputed reference material and that citations to Wikipedia are increasing quickly in scholarly works. Onwubiko (2012) discovered that the Internet lends its significance to the fax and mailing capacity at an unimaginable efficiency and speed of information dissemination. Also, Chen et al. (2012) found that, among the four types of communications, knowledge sharing attracts the largest volume of user responses on libraries social networking sites. In the same sequence, Divya and Sudhier (2019) conducted a study at the University of Kerala; the study reveals that email is the most preferred social networking services by research scholars in the University of Kerala followed by worldwide web used for research dissemination. Accordingly, the average score of the male researchers' use of search engine is slightly greater than that of female; while females preferred ResearchGate, Academia.edu, getCITED.org, Social Science Research Network use than the male respondents. Further evidence shows that there is no agreement between social networking tools and services concerning gender for research communication.

In the same vein, Singh and Gill (2011) carried out a study through a structured questionnaire which was administrated among research scholars pursuing their research at GND University, Amritsar. The study found that majority of the respondents were aware of social networking sites and are actively using such applications in their research works. The study of Bicen and Cavus (2010) investigated the internet usage of researchers and the extent to which social network sites are preferred by the participants. A questionnaire was used to collect data on the opinions of participants about their preference of social network sites for their research work. Results of the study showed that Live Spaces and Facebook were the preferred tool by the participants. In that sequence, Khan (2012), conducted a survey study on the "use of information sources by faculty members, research scholars and students of the faculty of commerce, AMU, Aligarh." The purpose was to find out the level to which they use information sources. The survey reveals that the maximum number of Faculty Members, as well as Research Scholars, uses Journals for getting their needed research information, while Students prefer general books for getting their research information. Using the quantitative research method based on the virtual snowball sampling approach, the study of Owan, Asuquo, Makuku et al. (2021), covering 24 African countries, revealed that the extent of staff willingness to adopt online tools for research dissemination was high; ResearchGate was the most utilised platform but many respondents indicated a higher rate of interest to utilise Google Scholar; $64.04 \%$ of scholars publication were on the internet across publishers, pre-print 
servers, repositories and social networks; many challenges were identified as limiting factors of the readiness to adopt internet platforms for research dissemination.

In the same vein, Singh and Pant (2013) conducted a study on the use of internet resources by the academic community of Mysore University, using a survey as the research tool. The study shows the frequency and length of use of the internet facilities by faculty members for research activities. The scholars discussed issues related to Internet-based reference with higher education institutions in South Africa and noted that librarians had access to the internet for a longer period than their users. Islam and Mostofa (2015) also carried out a study on "the usage pattern of Internet tools by the students of the information and communication science and library management department at Dhaka University". The study revealed that educational level, personality traits, age, gender, and geographical restriction influence the patterns of Internet utilization and their perceptions about the Internet. Ajani (2018) noted that the older generation of teachers (Digital immigrants) do not possess the technological knowledge, skills, and experiences that are necessary for research communication, they often hold negative perception and attitude towards the use of technology. The author, however, averred that teachers of the 21st century, most especially the Digital Native prefer digital technology for text communication. In terms of demographic factors another research by Owan, Asuquo, Owan et al (2021) found that gender and age significantly affected academic staff preparedness to adopt Internet tools for research sharing partially and interactively in African Universities during Covid-19; female staff were more prepared than males to adopt internet tools for research sharing during the pandemic; older lecturers reported a higher rate of preparedness than their younger colleagues to adopt Internet tools for research sharing during Covid-19.

\section{The need for the current study}

An exploration of the literature related to the present study suggests that there is relatively scarce literature on the subject matter. It is important to understand if the professional variables of academics affect their decision to use internet-based channels for research communication or otherwise. Unfortunately, studies seeking to improve the extent of ICT utilisation among scholars in varsities rarely consider staff professional variables. The researchers argue that the professional variables of staff are very important to be considered since they are personal attributes of academics. Furthermore, the professional variables of staff have been widely studied in another context as possible predictors of different dependent variables. For example, Gulyas (2013) assessed the influence of some professional variables such as length of career, media sector, and organisational size on the views and uses of social media by Journalists in Germany, the UK, Finland and Sweden. Other scholars have linked them to nurses' critical thinking (Zuriguel-Pérez et al., 2019), the effectiveness of the code of ethics for journalists (Mauri-Ríos et al., 2020), Self-Perceived Digital Competence of Social Educators (Gonzalez et al., 2020), as well as teachers' lifelong learning tendencies and burnout (Yildiz-Durak et al., 2020).

On these premises, the researchers believed that the professional variables of academics might affect their readiness to utilise electronic channels in communicating their findings, which may, in turn, affect their use of digital platforms. In an era where the Covid-19 pandemic succeeded in ravaging almost all the aspects of different economies, questioning the current systems available, it is pertinent to devise ways of getting ready for other future occurrences. However, effective preparation can only be made possible through an understanding of what constitute the current problems and the contributing or associated factors. In this study, the current study 
was designed to determine the extent to which staff professional variables (educational qualification, rank, length of service and area of research interest) affect the readiness to utilise internet-based channels for research communication (hereafter RUIBCRC) in Africa. The researchers hypothesised that staff professional variables (educational qualification, rank, length of service and area of research interest) have no significant partial effect on the RUIBCRC in African varsities.

\section{Theoretical framework}

This study will be anchored on Abraham Maslow's Theory of motivation. Maslow's hierarchy of needs is a psychological motivational theory that consists of a five-tier model of human necessities, which is sometimes shown as hierarchical tiers within a pyramid (see Fig. 1). People are driven to meet particular wants, according to Maslow (1943, 1954), and certain needs take precedence over others. Physical survival is our most fundamental necessity, and it will be the driving force behind our actions. When that level is completed, we are motivated to move on to the next level, and so on.

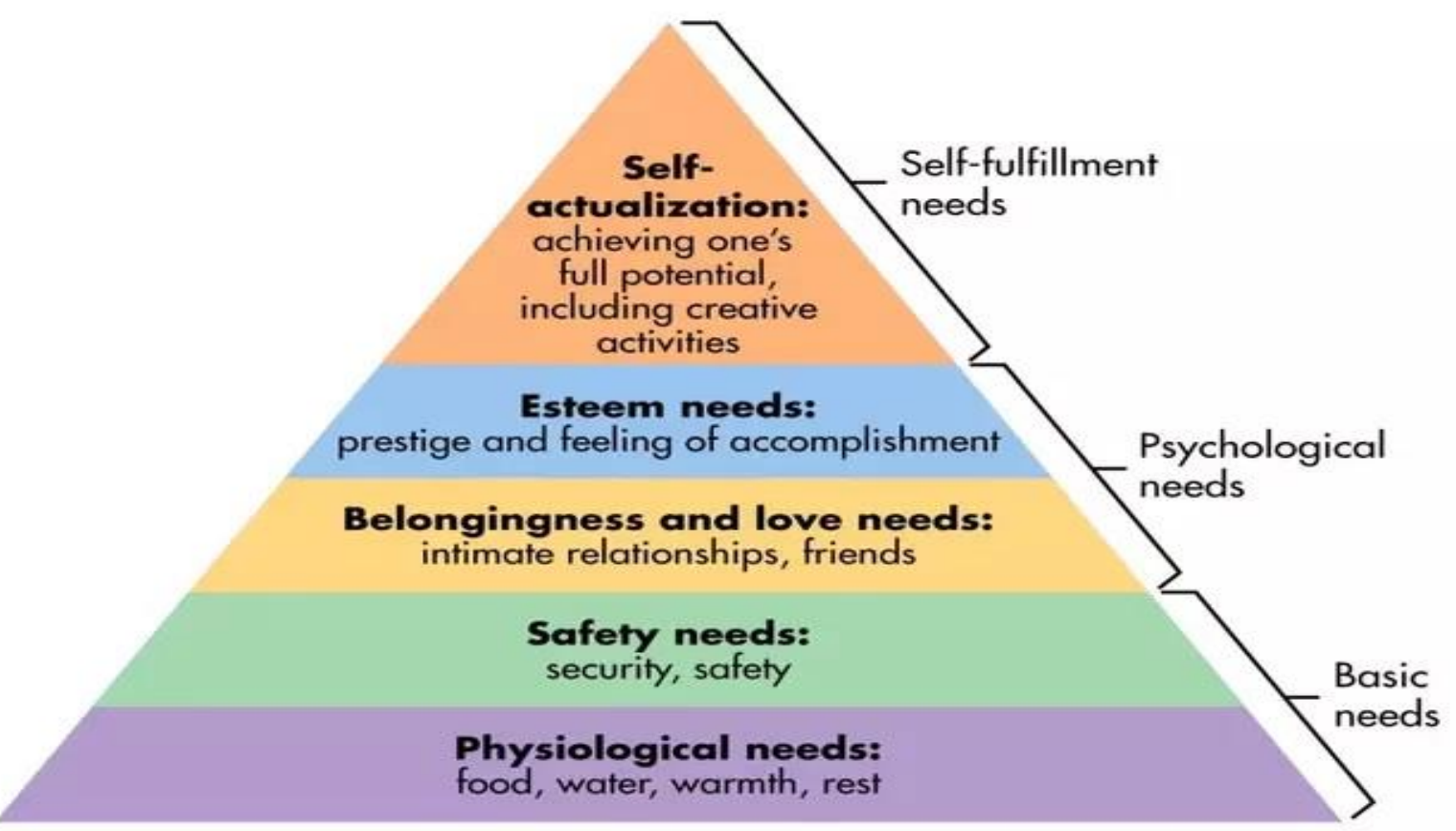

Fig. 1: Maslow's Hierarchy of Needs Theory

1. Physiological necessities - air, food, drink, shelter, clothes, warmth, sex, and sleep are all biological necessities for human life. The human body cannot operate efficiently if these demands are not met. Physiological needs are the most essential, according to Maslow, because all other wants are secondary until these are addressed.

2. Safety and security needs - after a person's physiological demands are met, safety and security become more important. In their daily lives, people seek to control, consistency, and direction. These requirements can be met by the family and society (e.g., police, schools, business and medical care).

3. Needs for love and belonging - when physiological and safety concerns are met, the third level of human needs is social, which includes feelings of belonging. An emotion-related need for interpersonal interactions, affiliations, connectivity, and being a member of a group is 
referred to as acceptance and belonging. Friendship, closeness, trust, and recognition, as well as receiving and giving affection and love, are all examples of a feeling of belonging desires. 4. Self-worth, accomplishment, and respect are the fourth level of Maslow's hierarchy of needs. Maslow divided esteem requirements into two categories: self-esteem (dignity, accomplishment, control, autonomy) and esteem for others (reputation or respect). For children and teenagers, the desire for respect or reputation is the most crucial, according to Maslow, and it comes before true self-esteem or dignity.

\section{Methodology}

For this research, the virtual cross-sectional survey design. A total of 8,591 academics in African universities were the targeted demographic of this study. There were $68.13 \%$ males $(\mathrm{N}$ $=1347)$ and $31.87 \%$ females $(\mathrm{N}=630)$ among the participants. A total of $180,450,627,360$, and 360 respondents, representing $9.10 \%, 22.76 \%, 31.71 \%, 18.21 \%$, and $18.21 \%$, were between the ages of 20 and 29, 30 and 39, 40 and 49, 50 and 59, and 60 years or older, respectively. In terms of educational attainment, $4.55 \%$ of respondents $(\mathrm{N}=90)$ held a first degree, 31.87 percent $(\mathrm{N}=630)$ held a master's degree, and 63.58 percent $(\mathrm{N}=1,257)$ held a doctorate. In terms of rank, 9.10 percent $(\mathrm{N}=180)$ of respondents were graduate assistants, $13.66 \%(\mathrm{~N}=270)$ were assistant lecturers, $22.76 \%(\mathrm{~N}=450)$ were grade II lecturers, $9.10 \%$ $(\mathrm{N}=180)$ were grade I lecturers, $18.21 \%(\mathrm{~N}=360)$ were senior lecturers, $18.06 \%(\mathrm{~N}=357)$ were associate professors/readers, and $9.10 \%(\mathrm{~N}=180)$ were full professors. In terms of respondents' countries of residence, a total of 6,17 and 15 respondents representing $0.30 \%$, $0.86 \%$ and $0.76 \%$ were residents of Algeria, Benin Republic and Botswana respectively. Residents of Cameroon, Egypt, the Gambia, Ghana, Kenya, Lesotho and Liberia were 24(1.21\%), $9(0.46 \%), 54(2.73 \%), 58(2.93 \%), 11(0.56 \%)$, and 18(0,91\%) respectively. Furthermore, $0.71 \%(\mathrm{~N}=14)$ were residents of Mauritius; $0.76 \%(\mathrm{~N}=15)$ were residents of Namibia; $1.62 \%(\mathrm{~N}=32), 0.81 \%(\mathrm{~N}=16), 0.40 \%(\mathrm{~N}=8), 0.86 \%(\mathrm{~N}=17), 0.46 \%(\mathrm{~N}=9)$, and $1.42 \%(\mathrm{~N}=28)$ were residents of Niger Republic, Rwanda, Senegal, Seychelles, Sierra Leone and South Africa respectively. Furthermore, 0.71\% ( $\mathrm{N}=14), 0.71 \%(\mathrm{~N}=13), 0.91 \%$ $(\mathrm{N}=18), 1.11 \%(\mathrm{~N}=22), 4.25 \%(\mathrm{~N}=84)$ and $73.90 \%(\mathrm{~N}=1461)$ were Sudanese, Tanzanians, Ugandans, Zambians, Zimbabweans and Nigerians respectively.

For data collection, an electronic survey with three major aspects was employed. Section one includes a lengthy cover letter outlining the purpose of the research, its duration, the anticipated delivery date, the type of response/data required, and an ethical statement outlining how privacy and confidentiality will be treated. Section 2 collected demographic data from respondents, such as gender, age, credentials, ranks, years of employment experience, study regions, and countries of residence. The third segment was broken down into six sub-sections. The first sub-section consists of a five-point grading system with a selection of 20 internet sites on which participants were intended to demonstrate their readiness to utilize them for research communication. The second sub-section included a closed-ended survey to determine staff attitudes on traditional and current approaches to research communication. The third sub-unit consisted of a checklist of 20 websites that respondents may check to see which ones they utilize for research communication. The fourth sub-section was designed to assess respondents' overall number of academic publications (including journal articles, theses/dissertations, conference papers, book chapters, and books). The fifth sub-division was concerned with determining the total number of academic articles available on the Internet by respondents (including those on the websites of publishers and those that are manually submitted to internet 
sites). The sixth sub-unit of section three was designed to allow respondents to give their perspectives on the challenges they face when seeking to distribute research via internet media.

The instrument was examined for face and content validity by three instructional technology specialists and two psychometrists from the University of Calabar's Faculty of Education. The e-survey was released on the Association of African Universities' Telegram forum, which includes 1,622 participants from diverse African nations and regions. Members of the organization were invited to complete the survey and publish it on their universities' internetbased forums. The poll was open from July 2020 through January 2021, covering seven months of data collecting. Following the completion of the survey, the supporting data was imported, translated to an Excel file (.xlsx), evaluated, cleaned, and re-coded (where necessary). A total of 1,977 scholars from African institutions responded to the poll. Coded data were analysed using descriptive and inferential statistics such as the Kruskal Wallis Non-parametric test. The non-parametric test was used because the data failed to meet the normality assumptions required in the parametric test (See Table 1).

\section{Results}

The data of this study were subjected to normality and outlier assessment using Histogram, Shapiro-Wilks, Q-Q plots, box plots and scatterplots. The preliminary analysis revealed that the data failed the normality test using Kolmogorov-Smirnov and Shapiro-Wilk criteria (See Table 1). The results in Fig. 2 to 5, using box plots, also justified the normality test results in Table 1, but further revealed the absence of no notable outliers.

Table 1: Normality test using Kolmogorov-Smirnov and Shapiro-Wilk

\begin{tabular}{|c|c|c|c|c|c|c|c|}
\hline \multirow[t]{2}{*}{ Variables } & \multirow[t]{2}{*}{ Levels } & \multicolumn{3}{|c|}{ Kolmogorov-Smirnov ${ }^{\mathrm{a}}$} & \multicolumn{3}{|c|}{ Shapiro-Wilk } \\
\hline & & Stat. & Df & Sig. & Stat. & $\mathrm{df}$ & Sig. \\
\hline \multirow{3}{*}{ Educ. Qualification } & First Degree & & 90 & & & 90 & \\
\hline & Master's Degree & .21 & 630 & .00 & .88 & 630 & .00 \\
\hline & Doctorate Degree & .24 & 1257 & .00 & .84 & 1257 & .00 \\
\hline \multirow[t]{7}{*}{ Rank } & Graduate Assistant & .34 & 180 & .00 & .64 & 180 & .00 \\
\hline & Assistant Lecturer & .39 & 270 & .00 & .65 & 270 & .00 \\
\hline & Lecturer II & .45 & 450 & .00 & .55 & 450 & .00 \\
\hline & Lecturer I & .34 & 180 & .00 & .64 & 180 & .00 \\
\hline & Senior Lecturer & .22 & 360 & .00 & .84 & 360 & .00 \\
\hline & Assoc. Professor/Reader & .34 & 357 & .00 & .71 & 357 & .00 \\
\hline & Professors & .34 & 180 & .00 & .64 & 180 & .00 \\
\hline \multirow[t]{4}{*}{ Work experience } & Less than 3 years & .34 & 180 & .00 & .64 & 180 & .00 \\
\hline & $3-6$ years & .27 & 630 & .00 & .83 & 630 & .00 \\
\hline & 7 - 10 years & .34 & 180 & .00 & .64 & 180 & .00 \\
\hline & 11 years and above & .27 & 987 & .00 & .84 & 987 & .00 \\
\hline \multirow[t]{6}{*}{ Research Areas } & Social Sciences & .23 & 540 & .00 & .83 & 540 & .00 \\
\hline & Education & .31 & 357 & .00 & .74 & 357 & .00 \\
\hline & Pure/Applied Sciences & .33 & 360 & .00 & .77 & 360 & .00 \\
\hline & Arts and Humanities & .18 & 360 & .00 & .86 & 360 & .00 \\
\hline & Medical Sciences & .34 & 180 & .00 & .64 & 180 & .00 \\
\hline & Management Sciences & .34 & 180 & .00 & .64 & 180 & .00 \\
\hline
\end{tabular}




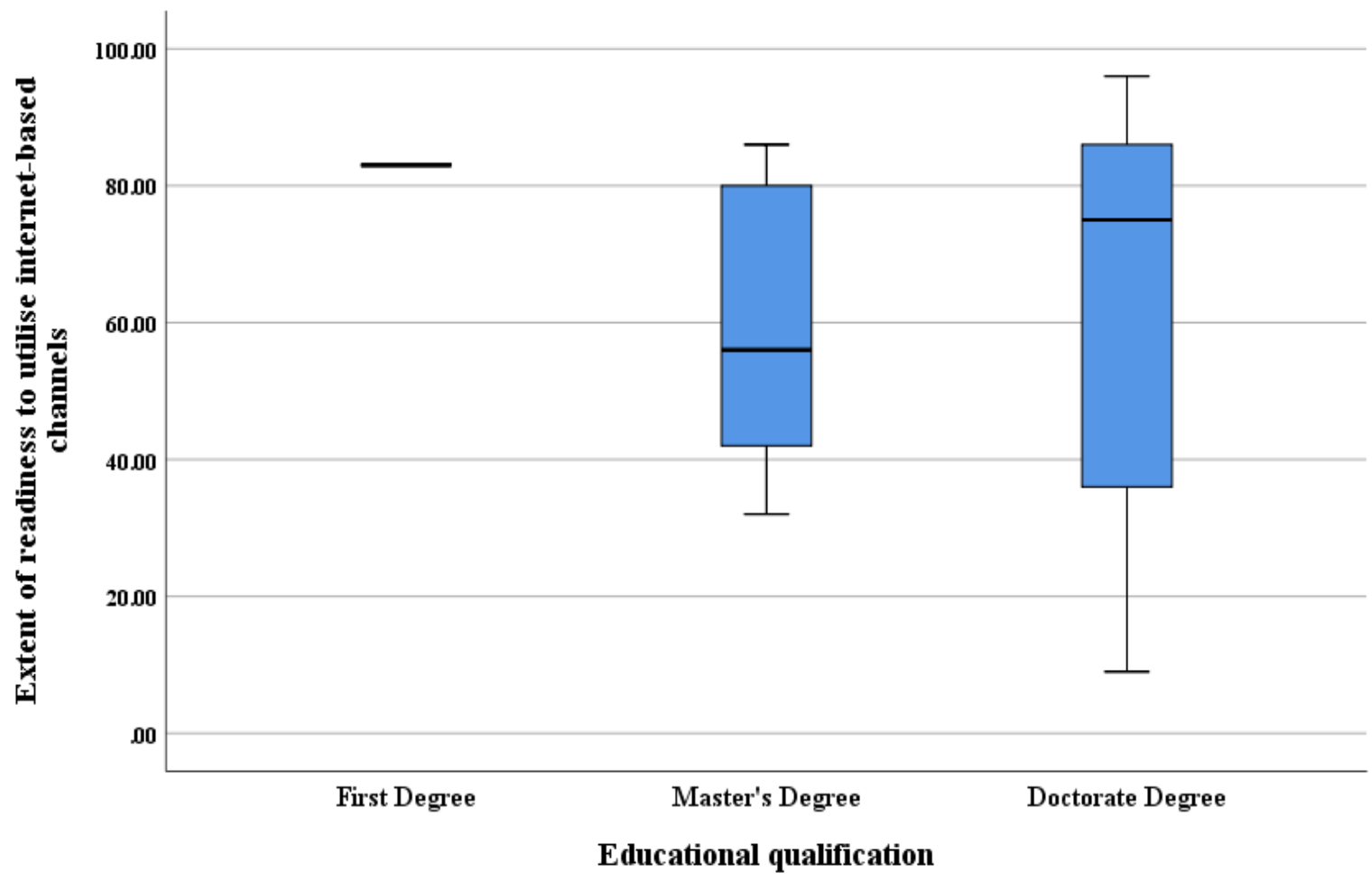

Fig. 2. Box plot showing the distribution of staff RUIBCRC based on educational qualification

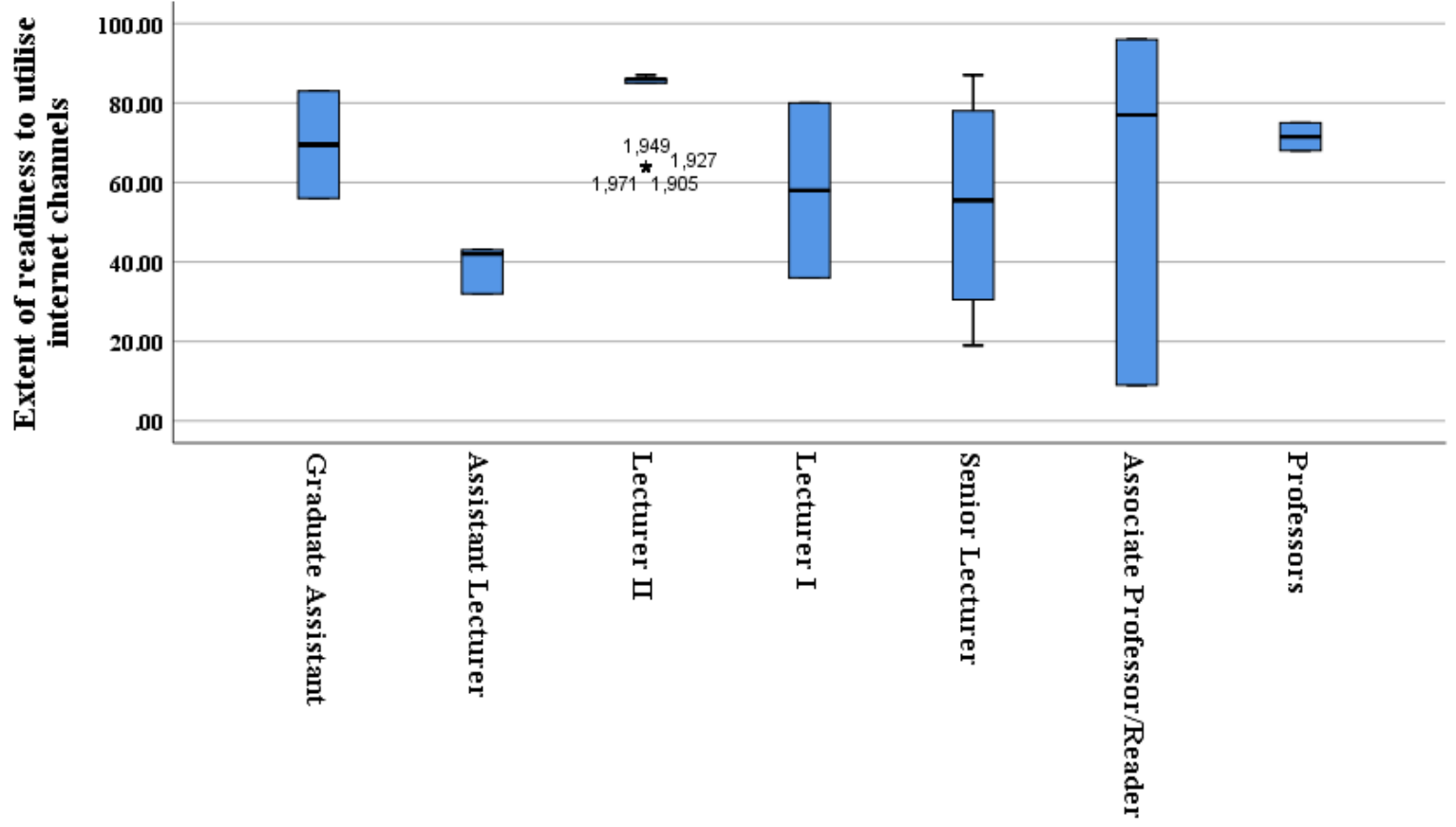

Rank

Fig. 3. Box plot showing the distribution of staff RUIBCRC based on rank 


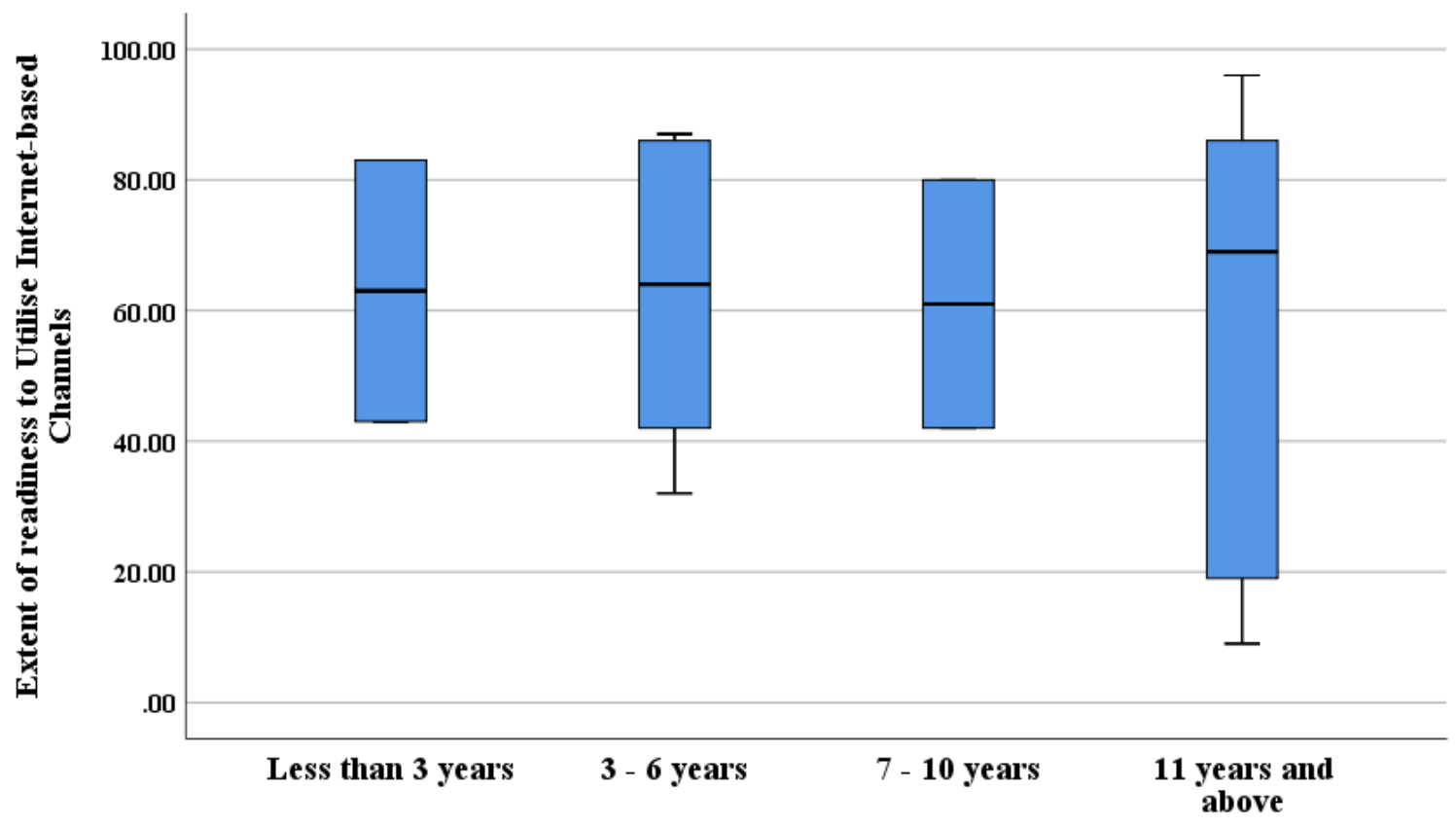

Years of Work Experience

Fig. 4. Box plot showing the distribution of staff RUIBCRC based on years of work experience

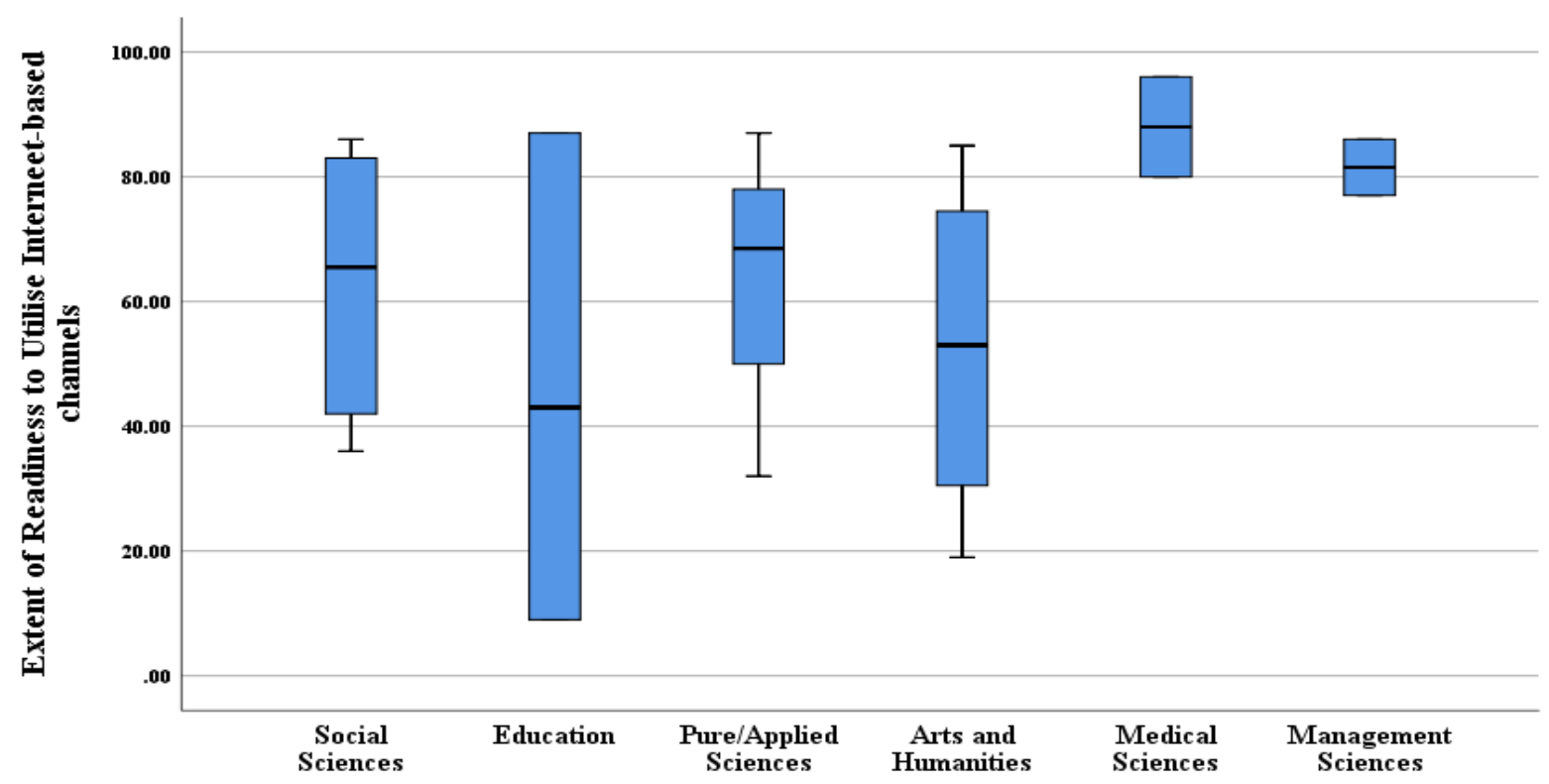

Research Areas

Fig. 5. Box plot showing the distribution of staff RUIBCRC based on research areas 


\section{Staff educational qualification and staff RUIBCRC}

The influence of educational qualification on staff readiness to utilise internet-based channels for research communication was assessed. A Kruskal Wallis test was performed to compare the mean ranks of staff across three categories of educational qualification (First, Masters and Doctorate degrees). The result, presented in Table 2, found significant mean rank differences in staff readiness to utilise internet-based channels for research sharing based on their educational qualifications $(\mathrm{H}[2]=79.08, \mathrm{p}<.05)$. Based on this evidence, the null hypothesis was discarded while the alternative hypothesis was adopted. To determine which of the groups are significantly different, the Bonferonni adjusted multiple comparison post hoc test. The post hoc test revealed a significant mean rank difference in the RUIBCRC between master's and doctorate holders; masters and first-degree holders; and doctorate and first-degree holders. The mean rank presented in Table 2 and depicted in Fig. 6, shows that the readiness to utilise internet-based channels for research communication is higher among doctorate holders. This is followed by those with first degree and master's degree holders. To understand whether the trend of staff readiness to utilise internet-based channels for research communication was increasing or otherwise based on educational qualification, the Jonckheere-Terpstra test was performed. The result of the analysis in Table 2 revealed a non-significant result $(\mathrm{J}=502200$, $\mathrm{z}=1.73, \mathrm{p}<.05)$. This implies that an increment in the readiness to utilise internet-based channel for research communication is not significantly associated with an increment in the educational qualification of staff.

Table 2: Results of Kruskal Wallis test of the differences in the RUIBCRC between the groups in the educational qualifications

\begin{tabular}{|c|c|c|c|c|c|c|c|}
\hline Levels & $\mathrm{N}$ & Mean Rank & Krusk: & Wallis & Jonckh & ere $\mathrm{Te}$ & tra test \\
\hline First Degree (FD) & 90 & 1392.5 & $\mathrm{H}(2)$ & $\mathrm{P}$ & $\bar{J}$ & $\mathrm{Z}$ & $\mathrm{P}$ \\
\hline Master's Degree (MD) & 630 & 865.36 & 79.08 & .000 & 502200 & 1.73 & 0.084 \\
\hline Doctorate Degree (DD) & 1257 & 1022.08 & & & & & \\
\hline Total & 1977 & & & & & & \\
\hline Pairwise comparisons o & IBCR & based on staf & ducatic & quali & tion & & \\
\hline Sample 1-Sample 2 & & Test Stat. & & & Std. Test & & Adj. $p$ \\
\hline $\mathrm{MD}-\mathrm{DD}$ & & -156.7 & 27. & & -5.64 & & .000 \\
\hline $\mathrm{MD}-\mathrm{FD}$ & & 527.1 & & & 8.212 & & .000 \\
\hline $\mathrm{DD}-\mathrm{FD}$ & & 370.4 & 62. & & 5.96 & & .000 \\
\hline
\end{tabular}




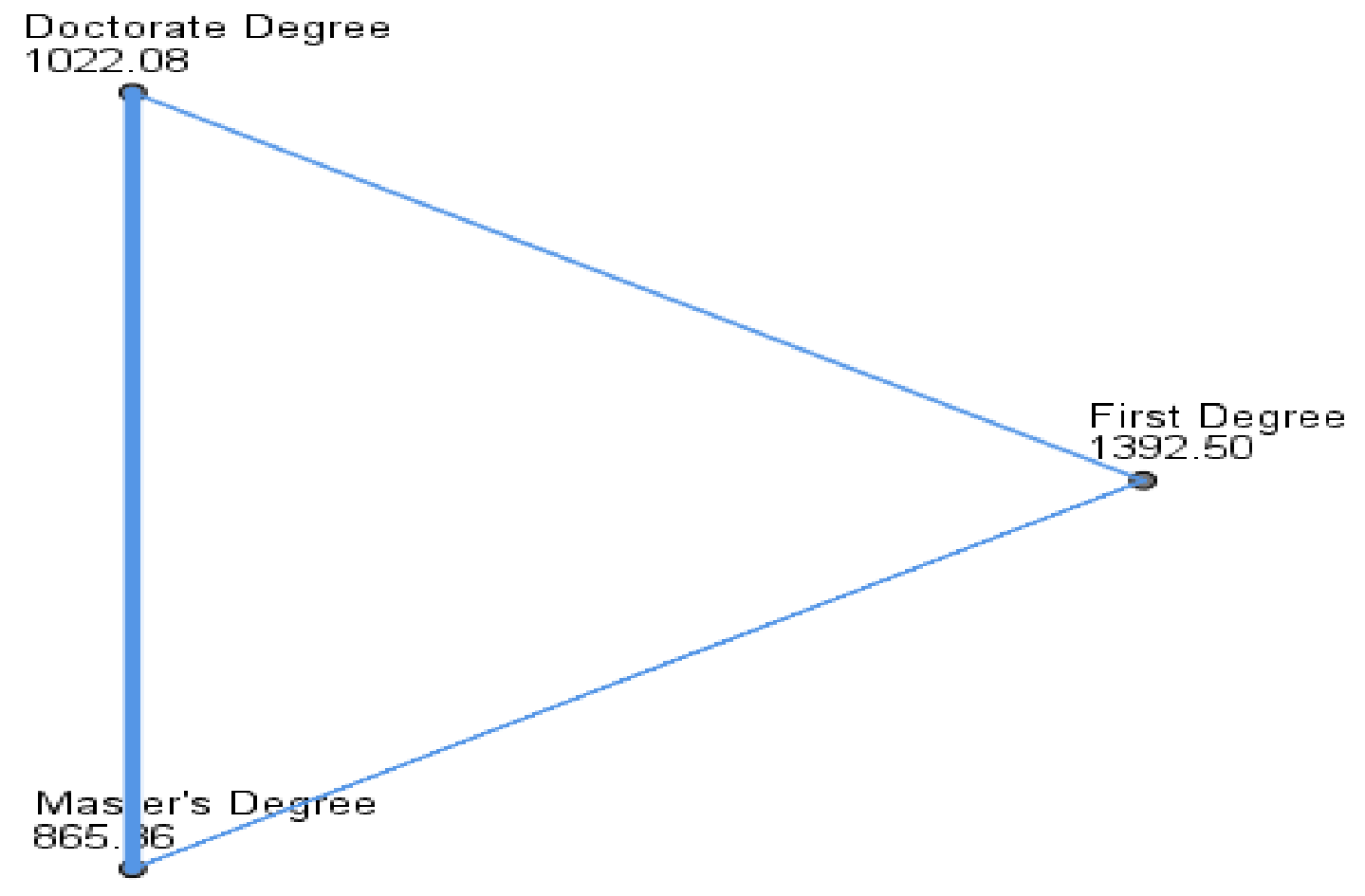

Fig. 6: Pictorial illustration of the pairwise comparisons of staff RUIBCRC based on their educational qualification

\section{Staff rank and staff RUIBCRC}

This study tested for the differences in the mean ranks of staff in the readiness to utilise internetbased channels for research communication based on their rank. A Kruskal Wallis test was performed and the results of the analysis (presented in Table 3 ) yielded a statistically significant result $(\mathrm{H}[6]=568.9, \mathrm{p}<.05)$. Based on this result, the null hypothesis was discarded, while the alternative hypothesis was upheld. Although the result is significant, it is not clear which of the groups differ significantly. To bridge this gap, the Bonferonni corrected test multiple of comparison was performed. The result in Table 3 showed that there is a significant difference in the RUIBCRC between assistant lecturers versus associate professors, lecturer $1 \mathrm{~s}$, senior lecturers, professors, graduate assistants, and lecturer 2 s respectively. The pairwise comparison also revealed a significant mean rank difference between Associate Professors versus Professors, Graduate Assistants and Lecturer 2s respectively, in the RUIBCRC. There is also a significant difference in the mean rank of Lecturer 1s versus Graduate Assistants and Lecturer $2 s$ in the RUIBCRC.

The evidence in Table 3 further revealed a significant difference in the mean rank of Senior Lecturers versus Graduate Assistants and Lecturer 2s respectively, in the RUIBCRC. More so, a significant difference was found in the RUIBCRC between Professors and Lecturer 2s; as well as, between Graduate Assistants and Lecturer 2s. However, a significant mean rank difference was not found between Associate Professors versus Lecturer 1s and senior lecturers respectively, in the RUIBCRC. No significant difference was also recorded between Lecturer 1s versus Senior Lecturers and Professors in the RUIBCRC respectively. There was no significant difference in the mean rank of Senior Lecturers and Professors regarding the 
RUIBCRC. Lastly, no significant difference was verified in the mean rank of Professors and Graduate Assistants in the RUIBCRC. The result depicted in Fig. 7 revealed that Lecturer 2s reported the highest level of readiness to utilise internet-based channels for research communication. This is followed by Graduate Assistants, Professors, Senior Lecturers, Lecturer 1s, Associate Professors/Readers and Assistant Lecturers. The Jonckheere-Terpstra test yielded a significant value $(\mathrm{J}=777060, \mathrm{z}=-2.96, \mathrm{p}<.05)$ indicating a trend that an increase in rank is associated with an increase in staff readiness to utilise internet-based channels for research communication in African varsities.

Table 3: Results of Kruskal Wallis test of the differences in the RUIBCRC between the groups in the ranks of academic staff

\begin{tabular}{|c|c|c|c|c|c|c|c|c|}
\hline \multirow[b]{2}{*}{ Rank } & & \multirow[b]{2}{*}{$\mathrm{N}$} & \multirow[b]{2}{*}{ Mean Rank } & \multicolumn{2}{|c|}{ Kruskal Wallis } & \multicolumn{3}{|c|}{ Jonckheere-Terpstra Test } \\
\hline & & & & $\mathrm{H}(6)$ & $\mathrm{P}$ & $\mathrm{J}$ & $\mathrm{Z}$ & $\mathrm{P}$ \\
\hline \multicolumn{2}{|l|}{ Graduate Assistant (GA) } & 180 & 1077.5 & 568.9 & .00 & 777060 & -2.96 & .00 \\
\hline \multicolumn{2}{|l|}{ Assistant Lecturer (AL) } & 270 & 507.5 & & & & & \\
\hline \multicolumn{2}{|l|}{ Lecturer II (L2) } & 450 & 1473.5 & & & & & \\
\hline \multicolumn{2}{|l|}{ Lecturer I (LI) } & 180 & 852.5 & & & & & \\
\hline \multicolumn{2}{|l|}{ Senior Lecturer (SL) } & 360 & 897.5 & & & & & \\
\hline \multicolumn{2}{|c|}{ Associate Professor/Reader (AP) } & 357 & 836.98 & & & & & \\
\hline \multicolumn{2}{|c|}{ Professors $(\mathrm{P})$} & 180 & 1032.5 & & & & & \\
\hline \multicolumn{2}{|c|}{ Total } & 1977 & & & & & & \\
\hline \multicolumn{9}{|c|}{ Pairwise comparisons of RUIBCRC based on staff ranks } \\
\hline \multicolumn{3}{|c|}{$\begin{array}{ll}\text { Sample 1-Sample 2 } & \text { Test Stat. } \\
\end{array}$} & SE & & \multicolumn{2}{|c|}{ Std. Test Stat. } & \multicolumn{2}{|c|}{ Adj. Sig. } \\
\hline Asst Lect-Assoc. Prof & \multicolumn{2}{|c|}{-329.48} & 45.94 & & \multicolumn{2}{|c|}{-7.17} & \multicolumn{2}{|c|}{.00} \\
\hline Asst Lect-Lect 1 & \multicolumn{2}{|c|}{-345.00} & 54.81 & & \multicolumn{2}{|c|}{-6.29} & \multicolumn{2}{|c|}{.00} \\
\hline Asst Lect-Sen Lect & \multicolumn{2}{|c|}{-390.00} & 45.86 & & -8.5 & & & \\
\hline Asst Lect-Prof & -525 & 5.00 & 54.81 & & -9.5 & & & \\
\hline Asst Lect-Grad Asst & 570 & .00 & 54.81 & & 10. & & & \\
\hline Asst Lect-Lect 2 & -966 & 5.00 & 43.85 & & -22 . & & & \\
\hline Assoc. Prof-Lect 1 & 15. & & 52.07 & & 0.3 & & & \\
\hline Assoc. Prof-Sen Lect & 60. & & 42.55 & & 1.4 & & & \\
\hline Assoc. Prof-Prof & -195 & .52 & 52.07 & & -3.7 - & & & \\
\hline Assoc. Prof-Grad Asst & 240 & .52 & 52.07 & & 4.6 & & & \\
\hline Assoc. Prof-Lect 2 & 636 & .52 & 40.37 & & 15. & & & \\
\hline Lect 1-Sen Lect & -45 & .00 & 52.00 & & -0.8 & & & \\
\hline Lect 1-Prof & -180 & 0.00 & 60.04 & & $-3 .($ & & & \\
\hline Lect 1-Grad Asst & 225 & .00 & 60.04 & & 3.7 & & & \\
\hline Lect 1-Lect 2 & 621 & .00 & 50.24 & & 12.7 & & & \\
\hline Sen Lect-Prof & -135 & 5.00 & 52.00 & & -2.6 & & & \\
\hline Sen Lect-Grad Asst & 180 & .00 & 52.00 & & 3.4 & & & \\
\hline Sen Lect-Lect 2 & 576 & .00 & 40.28 & & 14. & & & \\
\hline Prof-Grad Asst & 45. & 00 & 60.04 & & 0.7 & & & \\
\hline Prof-Lect 2 & 441 & .00 & 50.24 & & 8.7 & & & \\
\hline Grad Asst-Lect 2 & -396 & 6.00 & 50.24 & & -7.8 & & & \\
\hline
\end{tabular}




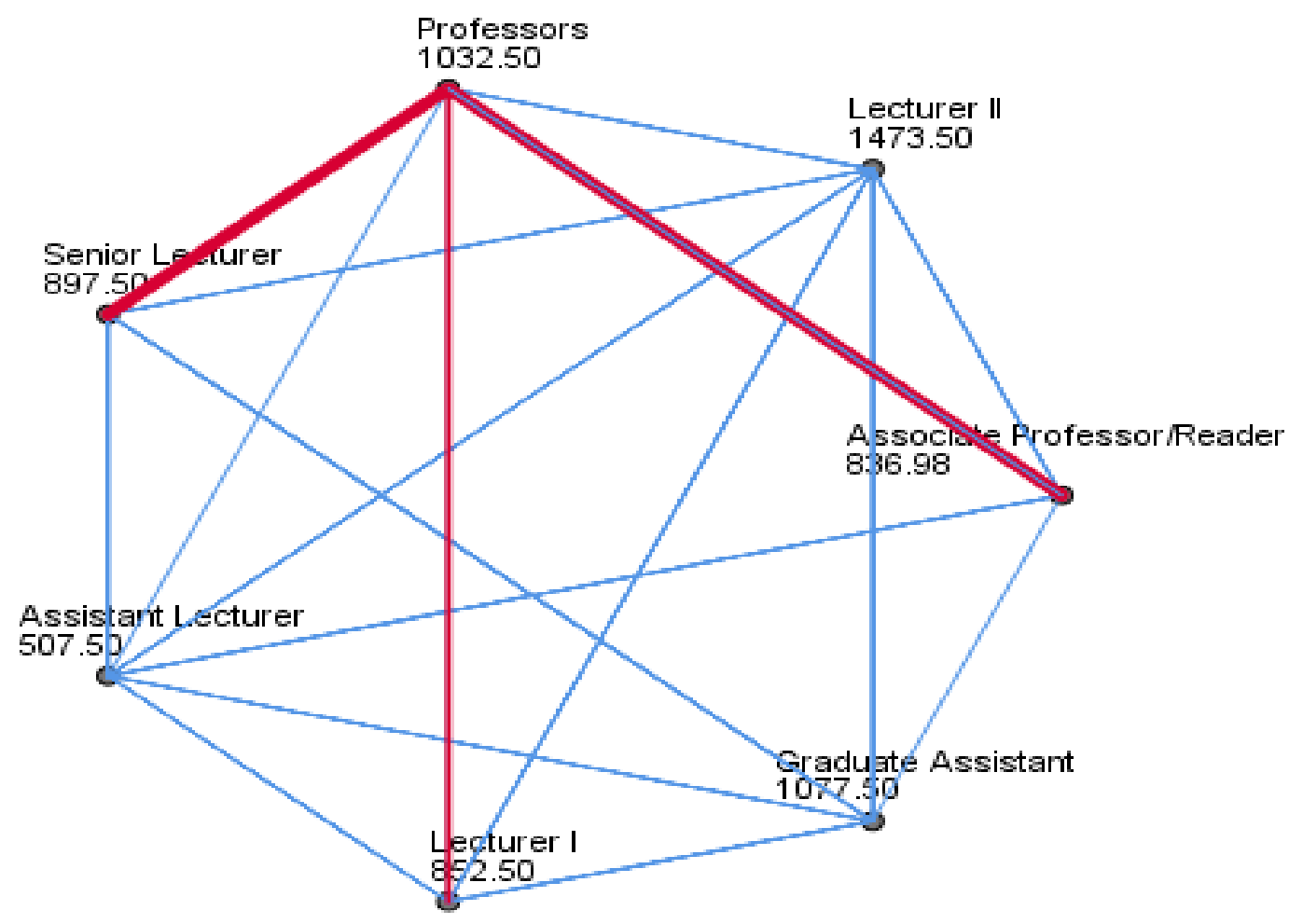

Fig. 7: Pictorial illustration of the pairwise comparisons of staff RUIBCRC based on their rank

\section{Length of service and staff RUIBCRC}

The influence of the length of service on staff readiness to utilise internet-based channels for research communication was assessed based on the differences that exist across staff with different years/length of service. A Kruskal Wallis test was performed to determine whether a significant difference exists across the various groups in the RUIBCRC in universities. The result of the analysis, presented in Table 4 showed a significant difference $(H[3]=15.16, p<$ $.05)$ in the readiness to utilise internet-based channels for research communication. Therefore, the null hypothesis was rejected while the alternative hypothesis was adopted due to the statistical support. Despite the significance of the result, it is yet to be known what groups differed significantly or otherwise. The Bonferonni correction post-hoc test of multiple comparisons was employed to compare the mean ranks of the pairwise groups of staff length of service. The result of the analysis, presented in Table 4, indicates that staff with 7 to 10 years length of service differed significantly in their mean rank from those with 3 to years length of service in their RUIBCRC in African universities. Staff with 11 years length of service or above also differed significantly from their counterparts with 3 to 6 years length of service in terms of the RUIBCRC. However, a significant mean rank difference was not recorded for staff with 7 to 10 years length of service and those with 11 years or above the length of service in their RUIBCRC.

The mean rank for staff with 7 to 10 years length of service is also significantly different from that of staff with less than 3 years length of service. Furthermore, staff with 11 years or more length of service did not differ significantly from those with less than 3 years length of service 
in the RUIBCRC. The result further indicated that staff with less than 3 years length of service do not differ significantly from their colleagues with 3 to 6 years length of service in the RUIBCRC in African universities. The result depicted in Fig 8 indicates that the mean rank in the RUIBCRC is higher in the group of staff with 3 to 6 years length of service. This is followed by the mean rank of those with less than 3 years length of service, 11 years or above length of service, and 7 to 10 years of service in descending order respectively. In understanding whether the trend in the RUIBCRC is increasing or otherwise with the length of service, the JonckheereTerpstra test was performed. The result of the analysis indicated that there is a significant association between length of service and staff RUIBCRC, such that an increase in the former, increases the latter $(\mathrm{J}=571050, \mathrm{z}=-3.51, \mathrm{p}<.05)$.

Table 4: Results of Kruskal Wallis test of the differences in the RUIBCRC between the groups in staff length of service

\begin{tabular}{|c|c|c|c|c|c|c|c|}
\hline \multirow[b]{2}{*}{ Length of service } & \multirow[b]{2}{*}{$\mathrm{N}$} & \multirow[b]{2}{*}{ Mean Rank } & \multicolumn{2}{|c|}{ Kruskal Wallis } & \multicolumn{3}{|c|}{ Jonckheere-Terpstra Test } \\
\hline & & & $\mathrm{H}(3)$ & $\mathrm{p}$ & $\mathbf{J}$ & $\mathrm{Z}$ & $\mathrm{p}$ \\
\hline Less than 3 years $(\mathrm{A})$ & 180 & 1032.50 & 15.16 & .00 & 571050 & -3.51 & .00 \\
\hline $3-6$ years $(B)$ & 630 & 1051.79 & & & & & \\
\hline 7 - 10 years $(C)$ & 180 & 920.00 & & & & & \\
\hline 11 years and above (D) & 987 & 953.57 & & & & & \\
\hline Total & 1977 & & & & & & \\
\hline \multicolumn{8}{|c|}{ Pairwise comparisons of RUIBCRC based on staff length of service } \\
\hline Sample 1-Sample 2 & \multicolumn{2}{|l|}{ Test Stat. } & \multicolumn{2}{|c|}{ SE } & \multicolumn{2}{|c|}{ Std. Test Stat } & Adj. $p$ \\
\hline C-D & \multicolumn{2}{|l|}{-33.57} & \multicolumn{2}{|c|}{46.17} & \multicolumn{2}{|c|}{-0.73} & 1.00 \\
\hline C-A & \multicolumn{2}{|l|}{112.50} & \multicolumn{2}{|c|}{60.04} & \multicolumn{2}{|c|}{1.87} & .37 \\
\hline C-B & \multicolumn{2}{|l|}{131.79} & \multicolumn{2}{|c|}{48.14} & \multicolumn{2}{|c|}{2.74} & .04 \\
\hline D-A & \multicolumn{2}{|l|}{78.93} & \multicolumn{2}{|c|}{46.17} & \multicolumn{2}{|c|}{1.71} & .52 \\
\hline D-B & \multicolumn{2}{|l|}{98.21} & \multicolumn{2}{|c|}{29.05} & \multicolumn{2}{|c|}{3.38} & .00 \\
\hline A-B & \multicolumn{2}{|l|}{-19.29} & \multicolumn{2}{|c|}{48.14} & \multicolumn{2}{|c|}{-0.40} & 1.00 \\
\hline
\end{tabular}

\section{Area of research interest and staff RUIBCRC}

The influence of the area of research interest on the staff readiness to utilise internet-based channels for research communication was determined using a non-parametric test. A Kruskal Wallis test was performed to determine whether there is a significant difference in the average rank of staff RUIBCRC based on the areas of their research interest. The result of the analysis, presented in Table 5 yielded a significant mean rank difference $(\mathrm{H}[5]=487, \mathrm{p}<.05)$. The result led to the rejection and retention of the null and alternative hypothesis respectively. To understand the source of variation and the groups that differ significantly or otherwise, the Bonferonni correction test of multiple comparisons was performed, with the result summarised in Table 5. According to the results, all the pairwise comparison between the various yielded a significant mean rank difference except for the comparison between staff in the research area of education and those in the area of arts \& humanities; as well as, the comparison between staff in the area of social sciences and those in the area of pure/applied sciences. The result 
depicted in Fig. 8 suggest that staff with research areas in the medical sciences reported the highest extent of readiness to utilise internet-based channels for research communication. This is followed by those in the management sciences, pure/applied sciences, social sciences and education in that order. The Jonckheere-Terpstra tests showed a significant ascending trend in readiness to utilise internet-based channels for research communication based on the area of research interest $(\mathrm{J}=940410, \mathrm{z}=10.40, \mathrm{p}<.05)$.

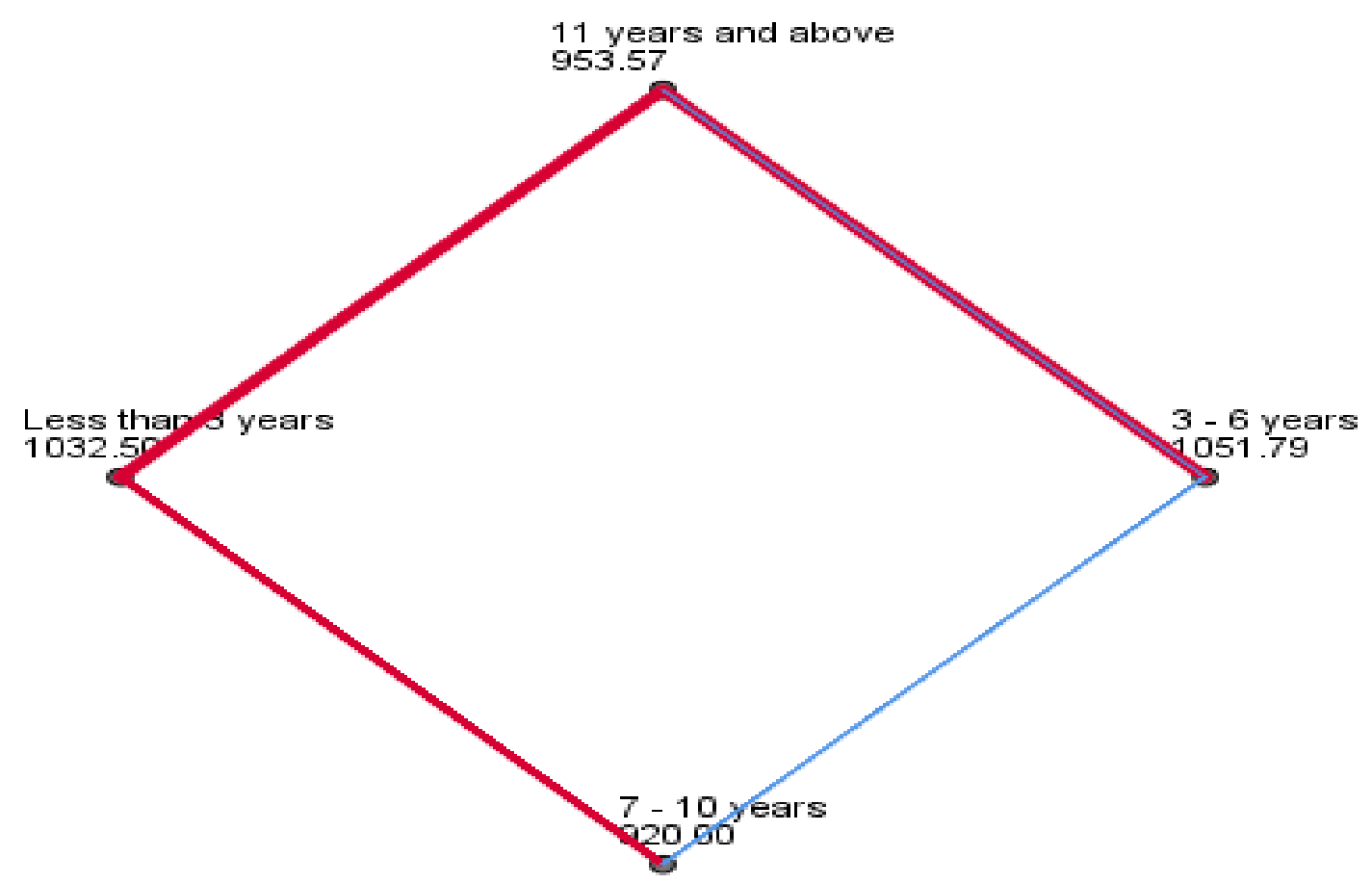

Fig. 8: Pictorial illustration of the pairwise comparisons of staff RUIBCRC based on the length of their service

Table 5: Results of Kruskal Wallis test of the differences in the RUIBCRC between the various group of the area of staff research interest

\begin{tabular}{lccccccc}
\hline & & Mean & \multicolumn{3}{c}{ Kruskal Wallis } & \multicolumn{3}{c}{ Jonckheere-Terpstra Test } \\
\cline { 5 - 8 } Area of Research interest & $\mathrm{N}$ & Rank & $\mathrm{H}(5)$ & $\mathrm{P}$ & $\mathrm{J}$ & $\mathrm{Z}$ & $\mathrm{p}$ \\
\hline Social Sciences & 540 & 972.50 & 487 & .00 & 940410 & 10.40 & .00 \\
Education & 357 & 666.82 & & & & & \\
Pure/Applied Sciences & 360 & 1021.25 & & & & & \\
Arts and Humanities & 360 & 773.75 & & & & & \\
Medical Sciences & 180 & 1617.50 & & & & & \\
Management Sciences & 180 & 1415.00 & & & & & \\
Total & 1977 & & & & & & \\
\hline
\end{tabular}

Pairwise Comparisons of RUIBCRC based on staff research areas

\begin{tabular}{lcccc}
\hline Sample 1-Sample 2 & Test Stat & SE & Std. Test Stat & Adj. P \\
\hline Edu - Arts\&Hum & -106.94 & 42.55 & -2.51 & .18 \\
Edu - Soc Sc & 305.69 & 38.86 & 7.87 & .00 \\
Edu - PA Sc & -354.44 & 42.55 & -8.33 & .00 \\
Edu - Mgt Sc & -748.19 & 52.07 & -14.37 & .00 \\
Edu - Med Sc & -950.69 & 52.07 & -18.26 & .00
\end{tabular}




\begin{tabular}{lcccc} 
Arts\&Hum - Soc Sc & 198.75 & 38.76 & 5.13 & .00 \\
Arts\&Hum - PA Sc & 247.50 & 42.46 & 5.83 & .00 \\
Arts\&Hum - Mgt Sc & -641.25 & 52.00 & -12.33 & .00 \\
ArtsHum - Med Sc & -843.75 & 52.00 & -16.23 & .00 \\
Soc Sc - PA Sc & -48.75 & 38.76 & -1.26 & 1.00 \\
Soc Sc-Mgt Sc & -442.50 & 49.03 & -9.03 & .00 \\
Soc Sci - Med Sc & -645.00 & 49.03 & -13.16 & .00 \\
PA Sc - Mgt Sc & -393.75 & 52.00 & -7.57 & .00 \\
PA Sc-Med Sc & -596.25 & 52.00 & -11.47 & .00 \\
Mgt Sci -Med Sc & 202.50 & 60.04 & 3.37 & .01 \\
\hline
\end{tabular}

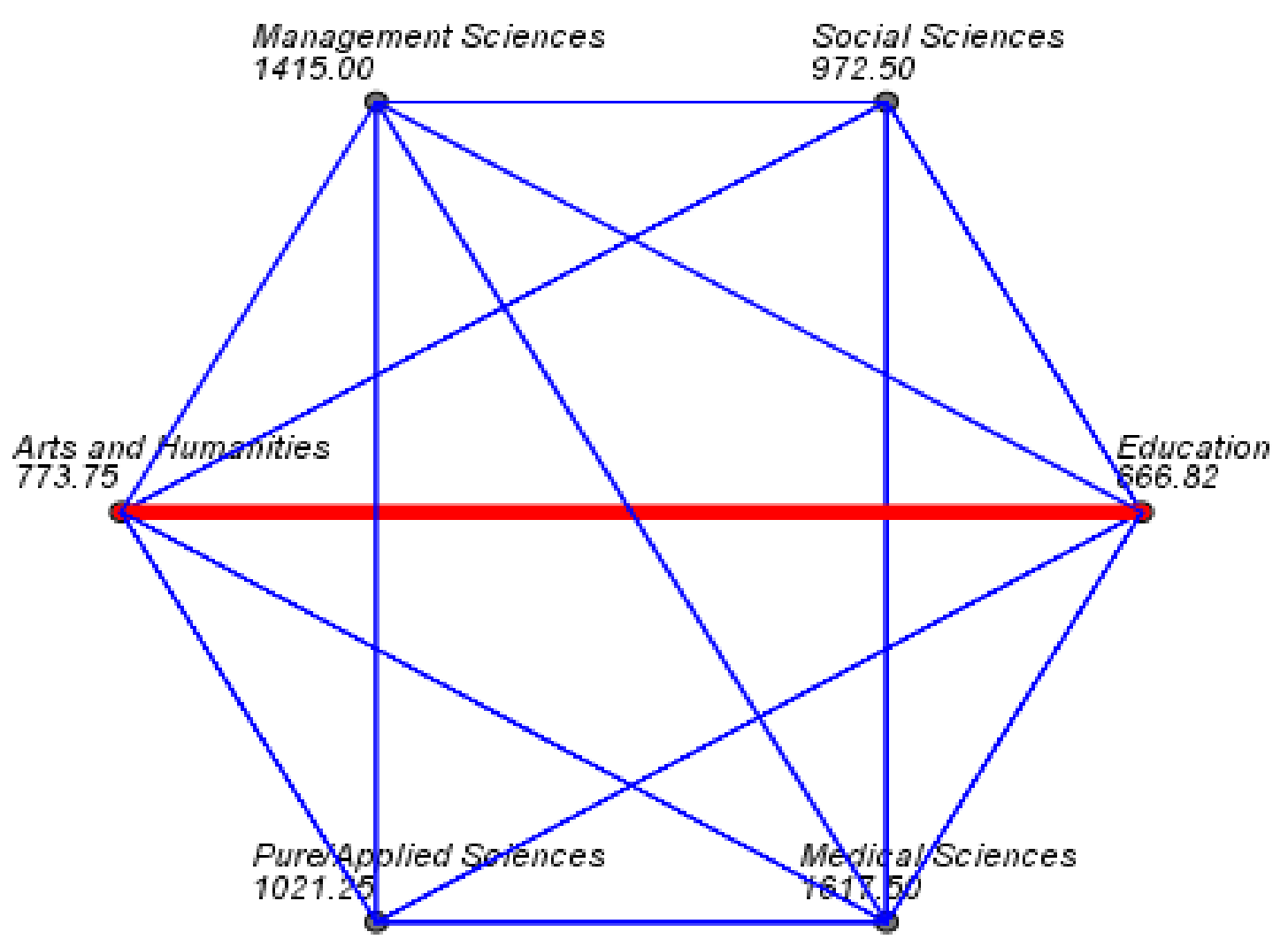

Fig. 8: Pictorial illustration of the pairwise comparisons of staff RUIBCRC based on the area of their research interest

\section{Discussion and Conclusion}

The finding to the first objective of this study established that there are considerable variances in staff preparedness to use internet-based channels for research communication based on their educational credentials. According to the survey, persons with a doctoral degree are more willing to use internet-based channels for research communication, followed by those with a first degree and those with a master's degree. This finding aligns with the research of Odigwe and Owan (2020) that revealed a significant difference in ICT utilisation based on staff educational qualifications and that ICT utilisation is a decreasing function of staff educational qualification. The result, however, disagrees with the finding of Alazzam et al. (2012) which found that educational qualification was not associated with the intention to use ICT among 
vocational and technical teachers, although doctoral degree holders demonstrated a higher extent of utilisation. The result also disagrees with the finding of Yushau and Nannim (2020) which did not find a significant difference in ICT use based on staff qualification. However, since the trend analysis of this study revealed that an increase in staff educational level is not substantially correlated with an increase in preparedness to use internet-based channels for research communication, there are some similarities between the opposing studies and the finding of this research.

This finding was anticipated because the educational qualification of an individual exposes them to experiences that shape their behaviours, wishes and actions. This may be the reason why staff with a doctoral degree indicated the highest level of propensity to use internet-based channels for research communication. This finding agrees with Abraham Maslow's hierarchy of needs theory that specifies that individuals' needs are in descending order and that higher needs are desired once the lower ones are met. This can be used to explain the results of this study. Doctoral degree holders are individuals who have accomplished their educational growth journey and are believed to be more involved in the business of research than others with lower qualifications. Thus, they should be more willing to make full use of available resources and technologies to advance their research careers. Scholars with master's or first degrees are probably more interested in studying for a higher qualification before thinking about research endeavours. Although the trend shows that the desire to use internet-based channels for research communication may not change even where the educational qualification does.

The finding of the second objective of this study revealed that personnel of varied academic positions differed in their propensity to use internet-based channels for research communication. The highest level of preparedness to use internet-based channels for research communication was indicated by Grade II lecturers (Lecturer IIs). Graduate Assistants, Professors, Senior Lecturers, Lecturer 1s, Associate Professors/Readers, and Assistant Lecturers follow in that order. This finding strengthens the finding of Odigwe and Owan (2020) which found significant rank differences in staff utilisation of ICT for research, teaching and records management. Despite the similarity, the cited study revealed that ICT use is a decreasing function of rank. The present study showed, on the contrary, that in African varsities, a rise in rank is correlated with an increase in staff readiness to use internet-based channels for research communication during the Covid-19 pandemic. The reason for the differences in results is not farfetched, the focus of the two studies is not the same, as ICT utilisation is not the same as the readiness to utilise internet-based channels.

It is not surprising that staff rank is connected to their readiness to utilise internet-based channels for research communication. This is because the research needs of academics with different rank differ, just as with those with different educational qualifications. Although it was expected that staff of higher rank will display a higher extent of readiness than those in the lower pecking order. However, the statistical evidence uncovered in this study did not provide support to this assumption. Against expectations, the first two categories of lecturers that indicated the strongest interest to utilise internet-based channels for research communication can be termed "junior academics" or "early-career researchers." An explanation for their increased interest may be attributed to their desires to build up a good reputation, tenure tracks and visibility as they climb the ranking ladder. Although, there is a mix when we consider the ordering from $3^{\text {rd }}$ position upwards; where professors and other senior academics dominate, before having other junior academics (assistant lecturers) occupying the last position. This may be attributed to individual differences, level of awareness or ICT exposure. However, the trend 
suggests that the readiness to utilise internet-based channels for research communication will be increasing as the rank of scholars increases. This seems to advance Maslow's Theory of motivation because other competitive needs of academics (such as skill acquisition, education, family, career advancements etc) would have been met at the lower rank, giving them room to focus on less important needs (such as the use of internet tools for research dissemination). It is usually at the top ranks that there is a strong research emphasis to publish and promote visibility.

The conclusion of the third objective of this study demonstrated a substantial variation in the readiness of personnel with varying lengths of service to use internet-based channels for research communication. Staff with 3 to 6 years of service reported the highest level of preparedness to use internet-based channels for research communication, followed by those with less than 3 years of service, 11 years or more of service, and 7 to 10 years of service, in that order. This finding is consistent with the results of Yushau and Nannim (2020) which showed significant differences in the use of ICT among lecturers with different years of service. The finding, however, disagrees with Gil-Flores et al. (2017) that found teaching experience and gender to be insignificant in predicting classroom ICT use in secondary schools. In the present study, the trend showed that there is a considerable relationship between duration of service and staff RUIBCRC, with the latter increasing as the former increases. This aligns with the results of Yushau and Nannim (2020) that scholars with the highest duration of service utilised ICT tools more than those with the lowest duration of training. The result does not tally with the finding of Hlengwa et al. (2018) which non-significant influence on years of teaching experience and perception to use ICT; although staff with a higher duration of work experience scored higher.

The key takeaway is that staff with short length service demonstrate a higher propensity to use internet-based resources for research dissemination. However, as they grow in the length of service, their actual utilisation of such tools increases with the duration of service. This result is not unexpected because staff who are newly employed tend to undergo retraining and are eager to do anything that will make them successful on the job. This finding has been able to explain that staff who have enjoyed a short duration of service are more willing to use internetbased channels for research communication. This finding agrees with the theory of motivation of Maslow because individuals have goals of reaching self-actualisation. To achieve this goal, such individuals must undergo a series of steps by meeting more pressing needs. Those with a longer duration of service may have reached or are closer to reaching self-actualisation than those who are relatively new to the job.

The discovery to the fourth objective of this study revealed a strong variation in the average rank of staff readiness to use internet-based channels for research communication depending on their research interests. Staff in the medical sciences indicated the greatest level of desire to use internet-based channels for research communication, followed by those in management sciences, pure/applied sciences, social sciences, Arts/Humanities and education, in that order. Based on the field of research interest, there is a substantial increasing trend in willingness to use internet-based channels for research communication. This finding may be attributed to the barriers academic staff of different disciplines face in attempting to use internet-based channels. This agrees with Mercader and Gairín (2020) that barriers to ICT adoption vary with academic discipline; with staff in the field of arts/humanities, social sciences and others encountering barriers such as a lack of planning, assessment, technological support, organisational culture, infrastructure, ineffective leadership and so on. In fact, according to Velasco (2011), instructors in the arts and humanities are the ones who see the largest 
impediments to incorporating digital technology in almost every scenario. Although science and technology instructors encounter the fewest hurdles of all, according to Salcines et al. (2017), a barrier is occasionally perceived more in the rest of the academic disciplines (Shelton, 2014; Mercader \& Gairín, 2020). These barriers could be accountable reasons why academics in these areas of research indicated relatively low rates of intentions to use internet-based channels for research communication during the Covid-19 pandemic in African varsities.

\section{References}

Ajani A. H. (2018). Repositioning education: Responsibility of digital natives' teachers. A ResearchGate Preprint. https://doi.org/10.13140/RG.2.2.21520.46088

Alazzam, A-O., Bakar, A. R., Hamzah, R., \& Asimiran, S. (2012). Effects of Demographic Characteristics, Educational Background, and Supporting Factors on ICT Readiness of Technical and Vocational Teachers in Malaysia. International Education Studies, 5(6), 229-243. https://doi.org/10.5539/ies.v5n6p229

Ashraf, K., \& Haneefa, K. M. (2016). Scholarly use of social media. Annals of Library and Information Studies, 63(2),132-139. https://bit.ly/3uGVLMd

Bicen, H., \& Cavus, N. (2010). The most preferred social network sites by students. Procedia - Social and Behavioral Sciences, 2(2), 5864-5869. https://doi.org/https://doi.org/10.1016/j.sbspro.2010.03.958

Chen, D. Y.-T., Chu, S. K.-W., \& Xu, S.-Q. (2012). How do libraries use social networking sites to interact with users? Proceedings of the American Society for Information Science and Technology, 49, 1-10. https://doi.org/10.1002/meet.14504901085

Chen, N., Zhou, M., Dong, X., Qu, J., Gong, F., Han, Y., Qiu, Y., Wang, J., Liu, Y., Wei, Y. et al. (2020). Epidemiological and clinical characteristics of 99 cases of 2019 novel coronavirus pneumonia in Wuhan, China: A descriptive study. Lancet, 395(10223), 507513. https://doi.org/10.1016/S0140-6736(20)30211-7

Cohut, M. (2020). Covid-19 global impact: How the coronavirus is affecting the world. https://www.medicalnewstoday.com/articles/covid-19-global-impact-how-thecoronavirus-is-affecting-the-world

Divya, L. R., \& Sudhier, K. G. P. (2019). Use of social networking tools and services among research scholars at the University of Kerala. International Journal of Information Dissemination and Technology, 9(1), 23-28. https://doi.org/10.5958/2249$\underline{5576.2019 .00005 .0}$

Divya, L. R., \& Sudhier, K. G., P. (2015). Use of internet tools and services by research scholars of the University of Kerala. SRELS Journal of Information Management, 52(6), 471-478. https://doi.org/10.17821/srels/2015/v52i6/84325

Gil-Flores, J., Rodríguez-Santero, J., \& Torres-Gordillo, J.-J. (2017). Factors that explain the use of ICT in secondary-education classrooms: The role of teacher characteristics and school infrastructure. Computers in Human Behavior, 68, 441-449. https://doi.org/10.1016/j.chb.2016.11.057 
Gonzalez, M. C., Martin, S. C., \& Andrade, V. B. (2020). The self-perceived digital competence of social educators in Spain: Influence of demographic and professional variables. International Journal on Advanced Science Engineering, Information Technology, 10(6), 2251-2260. https://doi.org/10.18517/ijaseit.10.6.9246

Gulyas, A. (2013). The influence of professional variables on journalists' uses and views of social media: A comparative study of Finland, Germany, Sweden and the United Kingdom. Digital Journalism, $\quad 1(2), \quad 270-285$. https://doi.org/10.1080/21670811.2012.744559

Islam, M., \& Mostofa, M. (2015). The usage pattern of Facebook among the students of Dhaka University: A study. Annals of Library and Information Studies, 62(2), 133-137. http://op.niscair.res.in/index.php/ALIS/article/download/8162/434

Jeyshankar, R., Nachiappan, N., \& Suresh, M. (2016). Access and use of social networking sites (SNSs) among the postgraduate students of rural-based college of Tamil Nadu, India-A study. SRELS Journal of Information Management, 53(3), 237-241. https://doi.org/10.17821/srels/2016/v53i3/72245

Khan, A. M. (2012). Use of information sources by faculty members, research scholars and students of the faculty of commerce, AMU, Aligarh: A Survey. Library Philosophy and Practice (e-journal), Article 782. https://digitalcommons.unl.edu/libphilprac/782/

Kumar, A., \& Kumar, R. (2013). Use of Social Networking Sites (SNSs): A study of Maharishi Dayanand University, Rohtak, India. Library Philosophy and Practice (e-journal), Paper 1000. https://digitalcommons.unl.edu/libphilprac/1000

Lee, J., Hughes, T., Lee, M. H., Field, H., Rovie-Ryan, J. J., Sitam, F. T., ... \& Daszak, P. (2020). No evidence of coronaviruses or other potentially zoonotic viruses in Sunda pangolins (Manis Javanica) entering the wildlife trade via Malaysia. Ecohealth, 17(3), 406-418. https://doi.org/10.1007/s10393-020-01503-X

Liu, P., Chen, W., \& Chen, J.-P. (2019). Viral metagenomics revealed sendai virus and coronavirus infection of Malayan Pangolins (Manis Javanica). Viruses, 11, Article 979. https://doi.org/10.3390/v11110979

Marinoni, G., van't Land, H., \& Jensen, T. (2020). The impact of Covid-19 on higher education around the world. International Association of Universities (IAU) Global Survey Report. Paris: Cedex 15. https://bit.ly/2SOTyB0

Mauri-Ríos, M., Marcos-García, S., \& Zuberogoitia-Espilla, A. (2020). Analysis of professional perceptions relating to the effectiveness of codes of ethics for journalists in Spain. Journal of Information, Communication and Ethics in Society, 18(4), 511-528. https://doi.org/10.1108/JICES-11-2019-0123

Mercader, C., \& Gairín, J. (2020). University teachers' perception of barriers to the use of digital technologies: the importance of the academic discipline. Int J Educ Technol High Educ 17, 4. https://doi.org/10.1186/s41239-020-0182-x

Munshi, S. A. (2015). The use of social media and internet communication tools for academic purposes of the engineering students at Aligarh Muslim University (AMU). SRELS 
Journal of Information Management, 52(6), 479-487. https://doi.org/10.17821/srels/2015/v52i6/84326

Nash, M., \& Churchill, B. (2020). Caring during COVID-19: A gendered analysis of Australian university responses to managing remote working and caring responsibilities. Gender, $\begin{array}{llll}\text { Work } \& \text { Organization, } & \text { 833-846. }\end{array}$ https://doi.org/https://doi.org/10.1111/gwao.12484

Nigeria Centre for Diseases Control (NCDC, 2021). Covid-19 Nigeria: Confirmed cases by states. https://covid19.ncdc.gov.ng/

Odigwe, F. N., \& Owan, V. J. (2020). Academic staff personal variables and utilization of ICT resources for research, teaching and records management in higher education. Proceedings of the 8th Annual European Conference on Education (ECE, 2020), 107123. https://bit.ly/2GG36II

Onwubiko, C. P. C. (2012). Impact of the Internet on the research effort of academics at Abia State University, Uturu, (ABSU). Library Philosophy and Practice (e-journal), Article 835. https://digitalcommons.unl.edu/libphilprac/835

Owan, V. J., Asuquo, M. E., Makuku, V., \& Etudor-Eyo, E. (2021). The extent of online platforms utilization for scholarly research work dissemination: A survey of academic staff in African Universities. Library Philosophy and Practice (e-Journal), Article 5585. https://digitalcommons.unl.edu/libphilprac/5585

Owan, V. J., Asuquo, M. E., Owan, M. V., Aslam, S., \& Obla, M. E. (2021). Gender, age and staff preparedness to adopt internet tools for research sharing during Covid-19 in African varsities. Article in Press.

Park, T. K. (2011). The visibility of Wikipedia In scholarly publications. First Monday, 16 (8). http://www.firstmonday.org/htbin/cgiwrap/bin/ojs/index.php/fm/article/view/3492/3031

Rangaswamy, A., Moch, N., Felten, C., van Bruggen, G., Wieringa, J. E., \& Wirtz, J. (2020). The role of marketing in digital business platforms. Journal of Interactive Marketing, 51, 72-90. https://doi.org/https://doi.org/10.1016/j.intmar.2020.04.006

Ross-Hellauer, T., Tennant, J. P., Banelytė, V., Gorogh, E., Luzi, D., \& Kraker, P., Pisacane, L., Ruggieri, R., Sifacaki, E., \& Vignoli, M. (2020) Ten simple rules for innovative dissemination of research. PLoS Computational Biology, 16(4), Article e1007704. https://doi.org/10.1371/journal.pcbi.1007704

Sahoo, D. R., \& Sharma, D. (2015). Social networking tools for library services. International Journal of Innovations in Science, Engineering \& Technology, 2(3) 69-71. https://bit.ly/3yW4e1h

Salcines, I., González, N., \& Briones, E. (2017). University teaching profiles: Knowledge and professional use of the smartphone. Bordón, 69(2), 91-114. https://doi.org/10.13042/Bordon.2017.51445

Shelton, C. (2014). "Virtually mandatory": A survey of how discipline and institutional commitment shape university lecturers' perceptions of technology. British Journal of Educational Technology, 45, 748-759. https://doi.org/10.1111/bjet.12051 
Singh, G., \& Pant R. (2013). Use of the internet for research and educational activities by research scholars: A study of D.S.B. campus of Kumaun University-Nainital. International Journal of Information Library \& Society, 4(2), 193-199. https://bit.ly/3uFfj3r

Singh, K. P., \& Gill, M. S. (2011). Use of social networking sites by the research scholars: A study of Guru Nanak Dev University, Amritsar. Library Herald, 49(3), 229-241. https://bit.ly/3paiMpA

Singh, K. P., \& Gill, M. S. (2015). Role and users' approach to social networking sites (SNSs): A study of universities of North India. The Electronic Library, 33(1), 9-34. https://doi.org/10.1108/EL-12-2012-0165

Special Expert Group for Control of the Epidemic of Novel Coronavirus Pneumonia (SEGCENCP) of the Chinese Preventive Medicine Association (CPMA, 2020). Zhonghua liu xing bing Хие za zhi = Zhonghua liuxingbingxue zazhi (Z Safflower Epidemiology Journal), 41(2), 139-144. https://doi.org/10.3760/cma.j.issn.0254$\underline{6450.2020 .02 .002}$

Stilgoe, J., Lock, S. J., \& Wilson, J. (2014). Why should we promote public understanding of science, 23(1), 4-15. https://doi.org/10.1177/0963662513518154

Velasco, L. (2011). ICT in the classroom: The University of Santiago de Compostela. In J. Hernández Ortega, M. Pennesi Fruscio, D. Sobrino López, \& A. Vázquez Gutiérrez (Eds.), Educational experiences in the 21st century classrooms. Innovation with ICT. Barcelona: Ariel

Wacharapluesadee, S., Tan, C. W., Maneeorn, P., Duengkae, P., Zhu, F., Joyjinda, Y., ... \& Wang, L. F. (2021). Evidence for SARS-CoV-2 related coronaviruses circulating in bats and pangolins in Southeast Asia. Nature communications, 12(1), 1-9. https://doi.org/10.1038/s41467-021-21240-1

Williams, A. J., Peck, L., \& Ekins, S. (2017). The new alchemy: Online networking, data sharing and research activity distribution tools for scientists. F1000Research, 6, Article 1315. https://doi.org/10.12688/f1000research.12185.1

World Health Organization (WHO, 2020). Coronavirus disease 2019 (COVID-19): Situation report-36. https://bit.ly/3iuymef

Xiao, K., Zhai, J., Feng, Y., Zhou, N., Zhang, X., Zou, J. J., ... \& Shen, Y. (2020). Isolation of SARS-CoV-2-related coronavirus from Malayan pangolins. Nature, 583(7815), 286-289. https://doi.org/10.1038/s41586-020-2313-x

Yang, S., Shan, T., Xiao, Y., Zhang, H., Wang, X., Shen, Q., ... \& Zhang, W. (2021). Digging metagenomic data of pangolins revealed SARS-CoV-2 related viruses and other significant viruses. Journal of Medical Virology, 93(3), 1786-1791. https://doi.org/10.1002/jmv.26524

Yildiz-Durak, H., Seferoglu, S. S., \& Sen, N. (2020). Some personal and professional variables as identifiers of teachers' lifelong learning tendencies and professional burnout. Cypriot Journal of Educational Science. 259-270. https://doi.org/10.18844/cjes.v15i2.3797 
Yushau, B., \& Nannim, F. A. (2020). Investigation into the Utilization of ICT Facilities for Teaching Purposes among University Lecturers: Influence of Gender, Age, Qualification and Years of Teaching Experience. Pedagogical Research, 5(2), em0054. https://doi.org/10.29333/pr/7845

Zhang, T., Wu, Q., \& Zhang, Z. (2020). Probable pangolin origin of SARS-CoV-2 associated with the COVID-19 outbreak. Current Biology, 30(7), 1346-1351. https://doi.org/10.1016/j.cub.2020.03.022

Zuriguel-Pérez, E., Falcó-Pegueroles, A., Agustino-Rodríguez, S., del Carmen Gómez-Martín, M., Roldán-Merino, J., \& Lluch-Canut, M. T. (2019). Clinical nurses' critical thinking level according to sociodemographic and professional variables (phase II): A correlational study. Nurse Education in Practice, 41, Article 102649. https://doi.org/10.1016/j.nepr.2019.102649 